\title{
Laparoscopic Nephrectomy
}

\section{初期14例の検討及び腎腫瘍に対する術式}
1）小牧市民病院泌尿器科（部長：小野佳成），2）社会保険中京病院泌尿器科（部長：大島伸一）
3) 市立岡崎病院泌尿器科 (部長 : 絹川常郎), 4) 静岡済生会総合病院泌尿器科（部長：加藤範夫）
5) 成田記念病院泌尿器科 (部長：平林 聡)

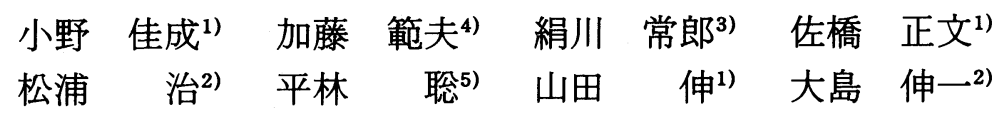

\section{LAPAROSCOPIC NEPHRECTOMY; RESULTS OF INITIAL 14 CASES AND PROCEDURE FOR RENAL CELL CARCINOMA}

\author{
Yoshinari Ono'), Norio Katoh"), Tsuneo Kinukawa ${ }^{3)}$, Masafumi Sahashi' ${ }^{1)}$, Osamu Matsuura ${ }^{2)}$, \\ Satoshi Hirabayashi ${ }^{5)}$, Shin Yamada ${ }^{1)}$ and Shinichi Ohshima ${ }^{21}$ \\ Departments of Urology, Komaki Shimin Hospital' ${ }^{11}$, Shakaihoken Chukyo Hospital' ${ }^{2}$, Okazaki City \\ Hospital $^{3)}$, Shizuoka Saiseikai General Hospital ${ }^{4)}$ and Narita Memorial Hospital ${ }^{5}$
}

Since July 1991, we have performed laparoscopic nephrectomy for removal of damaged kidneys in thirteen patients. In addition, we recently developed a new procedure of laparoscopic nephrectomy for renal cell carcinoma and successfully removed the kidney with renal cell carcinoma.

Patients' age ranged from 18 to 80 years with the average being 50 years. There were 8 male and 6 female patients. Original disease was calculous disease in 5 patients, vesicoureteral reflux in 4 , renovascular disease in 2 , ureteropelvic junction obstruction in 1, ectopic ureter in 1 and renal cell carcinoma in 1 . The mean size of the diseased kidney was $9 \times 5 \times 4 \mathrm{~cm}$ in the initial 13 cases and $13 \times 7$ $\times 6 \mathrm{~cm}$ in the case with renal cell carcinoma. The size of the tumor was $2.5 \times 2 \times 2 \mathrm{~cm}$. In the first 13 patients, nephrectomy was performed as diescribed previously. In the patient with renal cell carcinoma, a new procedure was applied. In the new procedure, five trocars were introduced into the abdominal cavity through the lateral abdominal wall. The kidney was removed en bloc together with the adrenal gland, perirenal fat and Gerota's fascia in the same fashion as traditional radical nephrectomy. Thirteen kidneys were successfully removed, but one failed because of dense adhesion to the surrounding tissue. Three of the 13 patients required additional laparotomies to control bleeding or to remove missed stone. There were no other severe complications in this series. The mean operative time was $308 \mathrm{~min}$ and the mean volume of estimated blood loss was $635 \mathrm{ml}$. The average hospital stay was 11 days after surgery.

These results indicate that (1) this procedure as currently carried out was not minimally invasive, however, does have the potential to become minimally invasive surgery and (2) a new procedure of laparoscopic nephrectomy for renal cell carcinoma might be applied for the patients with small volume renal cell carcinoma.

Key words: laparoscopic surgery, nephrectomy, radical nephrectomy, renal cell carcinoma

\footnotetext{
要旨：1991年 7 月より私共が経験した laparoscopic nephrectomy を施行した14例14腎の手術成績及び 14例目の腎腫瘍例に施行した新しい手術方法について報告した。はじめの13腎13例は萎縮腎あるいは水 腎症であり，その原因疾患は尿路結石，膀朕尿管逆流症，腎動脈狭窄症，腎孟尿管移行部狭窄症，尿管 異所開口で，腎の大きさは平均 $9 \times 5 \times 4 \mathrm{~cm}$ であった。

既に報告した方法で手術を行ったが，膿腎症であった 1 例 1 腎では周囲との強度の癒着のため腎の摘 出に失敗した。 3 例 3 腎に出血，結石の脱出がみられ，ともに開腹手術にて脾摘，被膜への小動脈結禁，
} 
結石の摘出を行った。なお, 脾摘例は膿腎症であった。腎腫瘍例を除く平均手術時間は 5 時間 2 分, 平 均出血量は $650 \mathrm{ml}$ であり, 手術から退院までの期間は平均11日であった。腎腫瘍例に対しては, 側腹部に 作製した 5 つの操作孔より, 腎, 副腎, 腎周囲脂肪織ともに Gerota 筋膜に被われたまま en bloc にて摘 出した. 合併症はなく, 手術時間は 6 時間 19 分, 出血量は $450 \mathrm{ml}$, 退院までの期間は 7 日であった. 腫瘍 は $2.5 \times 2 \times 2 \mathrm{~cm}$, 腎細胞癌 $\mathrm{G} 2$, PT1で摘出腎重量は $310 \mathrm{~g}$ であった. 本手術は minimally invasive surgery になりらると考兄られた。現時点で, 膿腎症は本手術の適応外とした方がよいこと, また, リンパ節転 移を伴わない小さな腎腫瘍は本手術のよい適応となることが示唆された。 キーワード：腹腔鏡下手術, 腎摘出術, 根治的腎摘出術, 腎腫瘍

\section{緒言}

私共は1991年 7 月より laparoscopic nephrectomy (腹腔鏡観察下腎摘出術)を試みてきた。最初, 萎縮腎 を対象として各種泌尿器疾患によって腎機能が廃絶し た腎を摘出してきたが，手術成績にまだ問題があるも のの手術創が小さく, 回復が早い点から minimally invasive surgeryになりらる方法であると考劣，更に 本手術の適応をひろげるために腎腫瘍に対する術式を 考案し試みた ${ }^{122)}$. 現在までの成績を報告するとともに 新しい術式を紹介しその結果も報告する。

\section{対象}

1991年7月より 1992年 6 月までに小牧市民病院，社 会保険中京病院, 市立岡崎病院, 静岡済生会総合病院, 成田記念病院の 5 施設で既に報告した方法で laparoscopic nephrectomy を施行した13例と，1992年 7 月に 新しい術式で腎腫瘍を有する腎を摘出した 1 例であ る. 対象 14 例の年齢は 18 歳から 80 歳, 平均 50 歳, 男性 8 例, 女性 6 例であった。 右側腎 5 例, 左側腎 9 例で, 原疾患は尿路結石 5 例, 膀胼尿管逆流症 4 例, 腎血管 性高血圧 2 例, 尿管異所開口 1 例, 腎孟尿管移行部狭 窄症 1 例, 腎腫瘍 1 例であった。手術腎機能は, 完全 あるいはほぼ廃絶13腎, 正常 1 腎であり, 廃絶してい た 13 腎は萎縮腎 8 腎, 水腎症 3 腎, 膿腎症 2 腎であっ た。また, 術前画像診断からの腎臓の大きさは, 腎腫 瘍例を除く 13 腎で平均 $9 \times 5 \times 4 \mathrm{~cm}$, 腎腫瘍例で $13 \times 7 \times$ $6 \mathrm{~cm}$ であった。

\section{方 法}

(i) 前処置

既に報告した方法に従い(12)，手術 3 日前より腸管前 処置として低残渣食を摂取, 非吸収性抗生剂を内服さ せ，術前日と術日に高圧浣腸を施行した。腎血管性高 血圧症の 2 例と VUR による萎縮腎の 1 例を除く 10 例 では術前日あるいは術日に腎動脈塞栓術をほどこし た。また，10例では手術直前に手術腎尿管に膀胱鏡的 にカテーテルを留置した。

\section{(ii) 手術方法}

1992年 6 月までの 13 例は既に報告した方法で施行し た ${ }^{12)}$. 本稿では14例目の腎腫瘍例に施行した新しい術 式について述べる. 全身麻酔下に約 $60^{\circ}$ の半側臥位に手 術台に固定した。手術台を $30^{\circ}$ 回転し，仰卧位に近い体 位として, Veress 針による気腹後, 鎖骨中線, 臍下 $1 \mathrm{~cm}$ の高さに $\phi 11 \mathrm{~mm}$ トラッカーを穿刺し, 操作孔 A とし た。腹腔鏡を挿入し観察下にその $6 \mathrm{~cm}$ 頭側に $\phi 5 \mathrm{~mm}$ のトラッカー, 前腋窩線, 臍下の高さに $\phi 11 \mathrm{~mm}$ のト ラッカーを穿刺し，それぞれ操作孔 B，Cとした。その 後, 手術台を逆に $30^{\circ}$ 回転させ完全な側臥位とした。電 気メスと把持鉗子を用い腎上縁の高さから前腸骨棘の 高さまで肝臓, 上行結腸外側の腹膜を切開した。次い

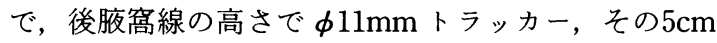
頭側で $\phi 5 \mathrm{~mm}$ のトラッカーを穿刺し, 操作孔 D, E と した．操作孔 Cより腹腔鏡（オリンパス社製・日本） による観察に変光, 操作孔 $\mathrm{A}, \mathrm{B} よ り の$ 鉗子 (Jarit 社 製・ドイッ) にて切開した腹膜端を把持して腹側へ牽 引し, 操作孔 $\mathrm{D}, \mathrm{E}$ からの鉗子にて腹膜と Gerota 筋膜 の間を腎上縁から下縁下方 $5 \mathrm{~cm}$ の高さまで遊離, 腎前 面を被う Gerota 筋膜を露出した。ここで腎静脈の同 定ができなかったので，さきに尿管を露出することと し, 腎下縁 $5 \mathrm{~cm}$ 下方で Gerota 筋膜を切開した。尿管内 に留置した尿管カテーテルに生理的食塩水を注入し, 尿管を確認した。操作孔 D, E からの鉗子にて尿管を遊 離し，カテーテル抜去後にクリップをかけ切断した。 腎下縁約 $2 \mathrm{~cm}$ 頭側の高さで十二指腸と Gerota 筋膜の 間を遊離し下大静脈前面, 側面を露出した。下大静脈 前面を頭側に向けて剝離露出し, 腎静脈を露出した. 操作孔 A より銁（Jarit 社製・ドイッ）を挿入し肝臓, 腸管を腹側へ圧排した。操作孔 D より単発式のリガ・ クリップ®（Ethicon 社製・USA）で腎静脈に下大静脈 起始部から 5 カ所にクリップをかけ， $3 \sim 4$ 番目のク リップの間で静脈をフック型剪刃（Stortz 社製・ドイ ッ）にて切断した。腎静脈の背側にある腎動脈を下大 
表 1 症例一覧

\begin{tabular}{|c|c|c|c|c|c|c|c|c|c|}
\hline 症例 & 性 & 年齢 & 患 & 側 & 腎の大きさ & 出血量 & 時間 & 摘出 & 合 併 症 \\
\hline 1 & 女 & 56 & 萎縮腎(腎尿管結石) & 右 & $7 \times 4 \times 3 \mathrm{~cm}$ & $400 \mathrm{ml}$ & $221 \mathrm{~min}$ & 成功 & \\
\hline 2 & 男 & 56 & 水腎症(尿管結石) & 左 & $7 \times 4 \times 3 \mathrm{~cm}$ & $400 \mathrm{ml}$ & $346 \mathrm{~min}$ & 成功 & 開腹：腎結石摘出 \\
\hline 3 & 女 & 43 & 水腎症(尿管結石) & 左 & $13 \times 7 \times 4 \mathrm{~cm}$ & $<100 \mathrm{ml}$ & $250 \mathrm{~min}$ & 成功 & \\
\hline 4 & 男 & 44 & 膿腎症(尿管結石) & 左 & $18 \times 11 \times 10 \mathrm{~cm}$ & & & 失敗 & 腸管損傷 \\
\hline 5 & 女 & 68 & 膿腎症(腎結石) & 左 & $10 \times 5 \times 3 \mathrm{~cm}$ & $3000 \mathrm{ml}$ & $270 \mathrm{~min}$ & 成功 & 開腹：脾摘 \\
\hline 6 & 女 & 41 & 萎縮腎(VUR) & 左 & $5 \times 3 \times 3 \mathrm{~cm}$ & $400 \mathrm{ml}$ & $285 \mathrm{~min}$ & 成功 & \\
\hline 7 & 男 & 18 & 水腎症(UPJ obstruction) & 左 & $9 \times 6 \times 4 \mathrm{~cm}$ & $<100 \mathrm{ml}$ & $289 \mathrm{~min}$ & 成功 & \\
\hline 8 & 男 & 54 & 萎縮腎(VUR) & 右 & $8 \times 4 \times 3 \mathrm{~cm}$ & $600 \mathrm{ml}$ & $345 \mathrm{~min}$ & 成功 & 開腹：止血 \\
\hline 9 & 男 & 36 & 萎縮腎(腎血管性高血圧) & 右 & $9 \times 5 \times 3 \mathrm{~cm}$ & $900 \mathrm{ml}$ & $549 \mathrm{~min}$ & 成功 & \\
\hline 10 & 男 & 50 & 萎縮腎(腎血管性高血圧) & 左 & $8 \times 5 \times 4 \mathrm{~cm}$ & $600 \mathrm{ml}$ & $218 \mathrm{~min}$ & 成功 & \\
\hline 11 & 男 & 80 & 水腎症(尿管異所開口) & 左 & $9 \times 5 \times 3 \mathrm{~cm}$ & $100 \mathrm{ml}$ & $242 \mathrm{~min}$ & 成功 & \\
\hline 12 & 女 & 38 & 萎縮腎(VUR) & 右 & $8 \times 3 \times 2 \mathrm{~cm}$ & $800 \mathrm{ml}$ & $329 \mathrm{~min}$ & 成功 & \\
\hline 13 & 女 & 61 & 萎縮腎(VUR) & 左 & $9 \times 4 \times 3 \mathrm{~cm}$ & $400 \mathrm{ml}$ & $282 \mathrm{~min}$ & 成功 & 気胸 \\
\hline 14 & 男 & 44 & 腎腫瘍 & 右 & $13 \times 7 \times 6 \mathrm{~cm}$ & $450 \mathrm{ml}$ & $379 \mathrm{~min}$ & 成功 & \\
\hline
\end{tabular}

UPJ obstruction；腎孟尿管移行部狭窄症, VUR；膀胼尿管逆流症

静脈背側から約 $2 \mathrm{~cm}$ にわたり剥離, 遊離しクリップを かけ剪刃で切断した。次いで下大静脈に沿って剥離を すすめ副腎静脈を遊離しクリップをかけ切離した。更 に下大静脈に沿って剥離をすすめ, 副腎との間を遊離 した。次いで腹膜と副腎の間を剝離，遊離した．操作 孔 B からの鉗子で Gerota 筋膜内内容を腹側へ倒すよ らにして, Gerota 筋膜と腸腰筋の間を操作孔 D, E か らの鉗子にて腎下縁から頭側へ腎上縁まで剥離，遊離 した. Gerota 筋膜内内容を操作孔 B からの把持鉗子 にて足方へ圧排し， $\phi 11 \mathrm{~mm}$ の操作孔に変えた操作孔 $\mathrm{E} ょ り$ 副腎上縁にクリップをかけ，切離し Gerota 筋 膜内内容を完全に遊離した。その後，出血のないこと を確認し, 一塊となった腎, 副腎, 周囲脂肪組織等の Gerota 筋膜内内容を腹腔内へ挿入した Lap Sac ${ }^{\circledR}$ (Cook 社製・USA) に入れるように操作したが, 摘出 内容がうまく入らず，操作孔 $\mathrm{A}$ と B の間を約 $5 \mathrm{~cm}$ 切 開し，操作孔 $A$ から挿入した把持鉗子(Wolf 社製・ド イッ) でGerota 筋膜内内容を把持し操作孔ごと体外 に摘出した.

\section{結 果}

膿腎症の 1 腎を除き，腎腫瘍例も含め 13 腎の摘出に 成功した。腎藏の摘出に失敗した 1 例では周囲組織, 特に下行結腸との癒着が強く腎藏前面の剥離中, 下行 結腸損傷を合併し，また，それ以上の剥離が困難なた め, 途中で開腹手術に切り換え腎を摘出した。腎腫瘍 例を除き，腎葴の摘出ができた12例の手術時間は218分 から549分, 平均 302 分であり, 推定出血量は $100 \mathrm{ml}$ 末満 から $3,000 \mathrm{ml}$, 平均 $650 \mathrm{ml}$ であった. $500 \mathrm{ml}$ 以上の出血
図 1 左腎摘出術での外套管の位置

左図：第 $1 \sim 13$ 例目までの13例

右困：第14例での位置を示す。右腎摘出術では左右 対称の位置においた。

\section{操作孔位置}

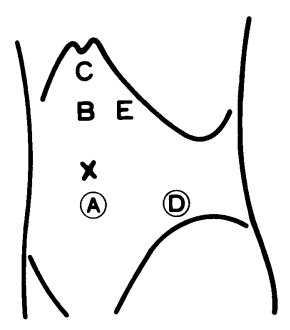

正中 $\mathrm{A}, \mathrm{B}, \mathrm{C}$ 鎖骨中線 E 前腋窩線 D

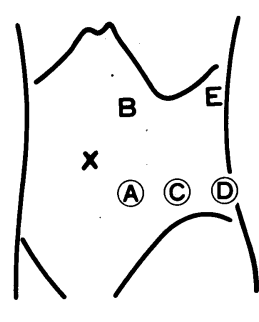

鎖骨中線 A, B 前腋窩線 C 後腋窩線 $\mathrm{D}, \mathrm{E}$
がみられた症例は 5 例あり, 症例 5 は, 左腎上極剝離 中に脾臓を損傷し, 腎摘出後も出血が続き損傷部を電 気入ス等による止血操作で止血できず開腹手術に切り 換光脾臓を摘出, 症例 8 は, 術前の動脈塞栓施行でき ず，左腎摘出後創部洗沙中に突然出血がみられ出血点 を検索するも判明せず, 後述する開腹手術を施行した。 症例 9,10は, 術前の動脈塞栓術施行できず, 腎剥離 中に腎周囲の小血管より出血, 大部分は電気メスにて 一部はクリップにて止血した。症例12は, 卵巣静脈剥 離中に卵巣静脈起始部で下大静脈が裂け出血, これを 下大静脈にクリップをかけ止血した。 なお, 出血の除 去は吸引で行った。腎腫瘍例の手術時間は379分, 推定 出血量は $450 \mathrm{ml}$ であった。腎臓の摘出に成功した 13 例 


\section{図 2 腎腫湟例の術前の CT 像}

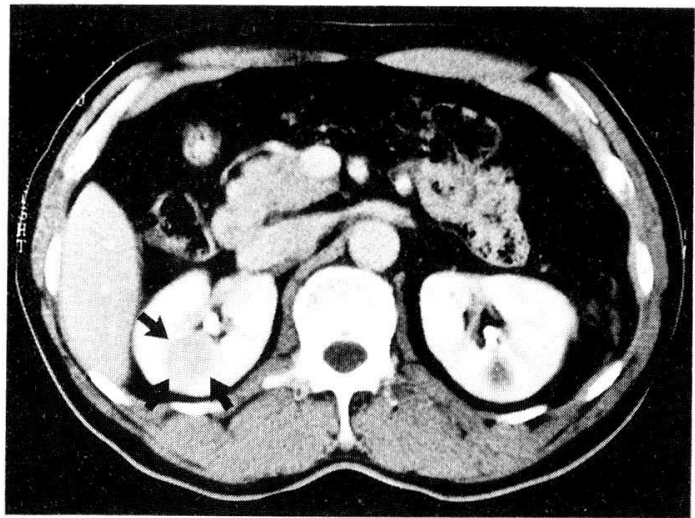

のらち 3 例に腎摘出後の出血，あるいは，腎孟から腹 腔内へ結石の脱出等の合併症をみとめ開腹手術を行 い，それぞれ，損傷した脾臓の摘出，腎被膜へ分布す る小動脈の結禁，結石の摘出を施行した。その他の合 併症では軽度な皮下気腫を 5 例にみとめたが，1術後 日には完全に消失していた。また，1例に術中横隔膜 の損傷より気胸を合併したが，腹腔鏡下で損傷部を把 持しクリップをかけ修復し, 術後の胸腔ドレナージに
より 2 術後日には保存的に治癒した，手術から退院ま での期間は開腹手術を行わなかった10例で 7 日から14 日，平均11日であった。

第14例目の腎腫瘍例では予定通り副腎，腎臓，腎周 团脂肪織を含め Gerota 筋膜に被われたままの摘出が 可能であった，本例では操作孔の位置がそれまでの 13 例とは異なったが，(1)正中線操作孔使用時にみられた 遊離腸管への鉗子のひっかかりが少なくなったこと。 (2)手術操作部への距離が短く操作が容易になったこ 之. (3)後腋窩線操作孔からの操作により腎上縁及び副 腎と肝臓下面との遊離が容易であったこと等の結果が 得られた。 また，本例の術後の病理学的検索では腫瘍 は大きさ $2.5 \times 2 \times 2 \mathrm{~cm}$, 腎細胞癌, 悪性度 2 , 偽被膜に 被われており， $\mathrm{pT}_{1} ， \mathrm{pV}_{0}$ であった。

\section{考察}

1990年 6 月の Clayman らの laparoscopic nephrectomy の臨床例での成功以来 ${ }^{4)}$, Coptcoat $5^{4)}$, 本 邦では, 私共 ${ }^{11}$, 東原 $5^{5)}$, 鈴木 $5^{6}$, 松田 $5^{71}$, が本手 術の追試を報告している. Clayman らは1992年 5 月ま でに腎癌，腎盂尿管腫瘍を含む本手術を施行した22例 の経験から，1例の失敗を除き 21 例で腎臓の摘出に成 功したと述べ，平均手術時間は約 5 時間と報告してい

\section{図 3 腎腫瘍例の摘出腎及び割面}
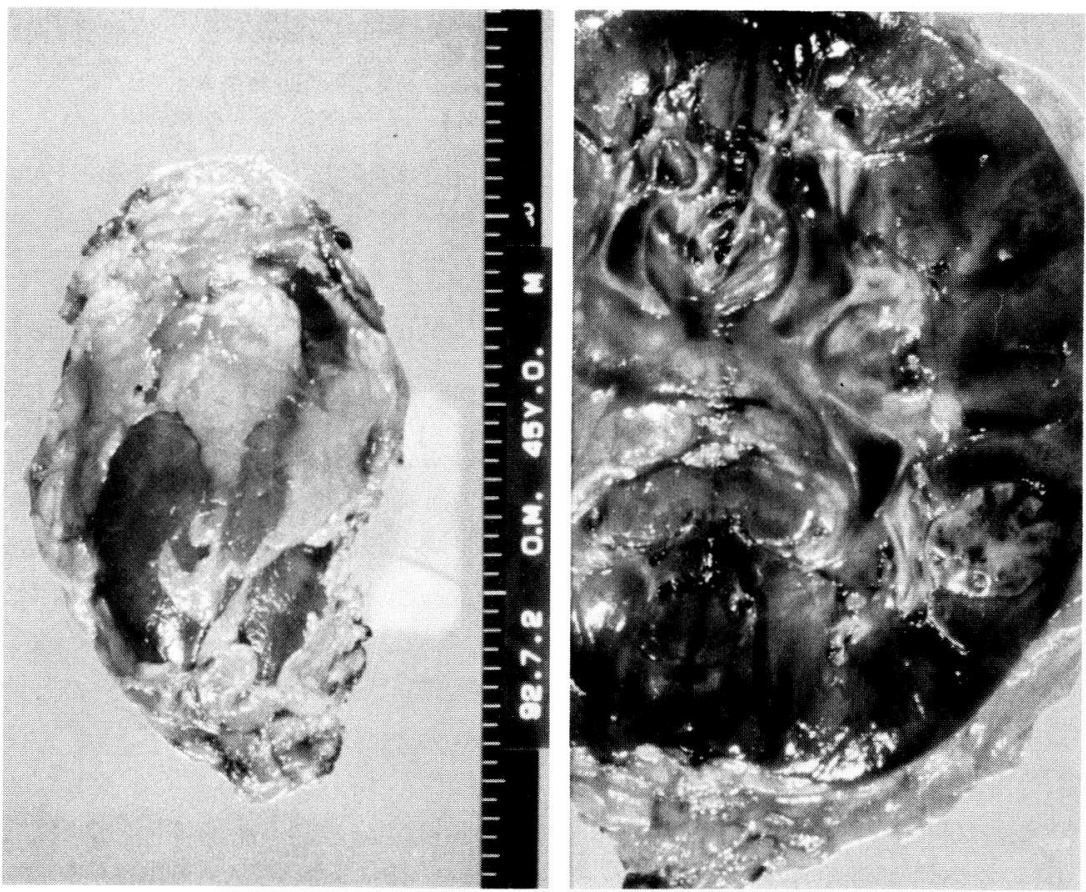
$3^{8)}$. Coptcoat らは27例の経験から，25例で腎摘に成 功，25例の $5 ち 2$ 例は止血のために開腹手術を施行し たと述べ，平均手術時間は 3 時間と報告している4). 両 者とも手術後の早期回復が得られ, 本手術が minimally invasive surgery であると述べている. 今回の私共 の腎腫瘍例を除く 13 例の成績では失敗 1 例，腎摘出後 の開腹手術例 3 例，平均手術時間 5 時間，平均入院期 間11日，平均出血量 $650 \mathrm{ml}$ とClayman らゃ Coptcort らの成績に比較し劣る。ひとつには，私共が経験した 症例数が少なくいわゆる learning curve effect が十分 にえられていない時点での成績であることや，現時点 では本手術の適応としては不適当と判断される膿腎症 2 例（1 例で失敗，他の 1 例は脾損傷から大量出量を 合併した）が含まれることによると考学られる．特に 膿腎症については, 従来の開腹手術においても周囲組 織との強固な癒着により手術操作に困難をきたすこと があることを考劣ると少なくとも現時点では，本手術 の適応からはずした方がよいと思われる。前述の Coptcoat らも私共と同様な経験から膿腎症例を除外 すべきと述べている，私共の成績を含め本手術の成績 を従来の開腹手術による腎摘出術と比較してみると, 手術創の大きさ，入院期間を除くと手術時間や出血量 で劣り, 現時点では, minimally invasive surgery と は云い難い。しかし，Copcoat らは手術時間が 3 時間 と述べて打り，また，出血量についても私共の症例で も前述の 1 例を除けば平均 $500 \mathrm{ml}$ 以下となり，本手術 が minimally invasive surgeryになりらる方法である と断定してもよいと考える.

今回報告した腎腫瘍例を除く13例は既に報告した方 法で手術を施行した，第14例については腎腫瘍例であ ることから副腎も含め Gerota 筋膜に被われたまま en bloc で摘出する必要から, 手術方法を方法の項で述べ たよらに変更した。その要点は，(1）操作孔の位置を

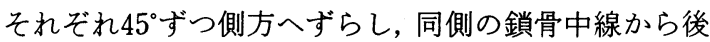
腋窩線までとする。（2）腹腔内で遊離した腎臓を袋に 入れ，袋ごと体外へ摘出する。（3）腎腫瘍では副腎,

腎藏，腎周囲脂肪織とともに Gerota 筇膜に被われた まま en bloc で摘出することとした。（1）操作孔の位 置を側方に変えることにより，13例までの正中線から の操作に比較して, 鎖骨中線からの操作では手術操作 部までの距離が短くなる，また，後腋窩線からの操作 により腎上極，副腎への到達及び操作が容易になるこ とを考兄て施行した．第14例に施行した操作孔の位置 は腎腫瘍腎の摘出のみならず他の疾患の腎摘出におい
ても有用であると考兄られた。（2）腎臓の摘出方法に ついては，当初，操作をより容易にするために皮切を 加兄直接腎臓を摘出していたが，第14例が腎腫瘍で あったことより，腫瘍細胞の播種を最小限にするため に，また，術後の病理検索のために摘出物を腹腔内で 特殊な袋に入れ, 細切はせずに腹壁に切開を加兄摘出 することにした。しかし，実際には袋への挿入に失敗 し摘出するのに約 $5 \mathrm{~cm}$ の皮切を加えた。将来的には松 田らが述べるように7), 本手術の本来の目的から考兄 れば少しでも皮膚切開を小さくするために腹腔内で腎 臓を特殊な袋に入れ，詳細な病理学的な検索を必要と しない良性疾患ではこれを細切して摘出すべきであろ 5.（3）腎腫瘍摘出手術時の腎臓, 副腎, 周囲脂肪織, Gerota 筋膜の en bloc 切除については今回述べたよ らな手術方法で可能であったが，可及的速やかな腎血 管の処理は困難であった。後者に関しては, 今後の課 題として残った。

最後に，腎腫瘍に対する本手術の適応について検討 する，通常の腎腫瘍に対する外科的切除方法は, Robson らの報告以来，腎臓と副腎を周囲脂肪織といっ しょに Gerota 筋膜につつまれたまま en block摘出 する radical nephrectomy が行われている9). 最近で は治療的な意義について未だ一定の結論は出ていない が, 大血管周囲のリンパ節郭清術も施行される ${ }^{10)}$. した がって，腎腫瘍例に本手術を行う場合には，現在のと ころ，(1）可及的速やかな腎血管の処理ができないこ と，（2）リンパ節郭清が行えないことが問題となる。 (1)に関しては動脈の塞栓術が施行してあることや本 手術では腎臓に用手的操作が加わらないために圧迫さ れたりすることが少なく腫瘍細胞の播種という点では むしろ risk は少ない可能性もある.（2）関しては，リ ンパ節転移の可能性の少ない症例に適応を限る必要が あろう。一般的に大きさが $3 \mathrm{~cm}$ 以下の腫瘍ではリンパ 節転移が生ずることはまれと言われており，当面これ らの症例を適応と考えるべきであろう，腎腫瘍に対す る本手術は，まだ第 1 例目であり手術時間や出血量の 点で開腹手術に劣ったが，今後 learning curve effect や手術器具の開発により成績の向上は充分期待でき る。また，手術創がない，あるいは極めて小さいこと， 入院期間が短い，回復が早い等の laparoscopic surgery の利点は大きな魅力であり，適応を選択すれば腎 腫瘍に対する治療法としても極めて有効な方法となり 得上5。

（本研究は，財団法人内視鏡医学研究振興の助成をらけ 
た.）

$$
\text { 文献 }
$$

1）小野佳成, 佐橋正文, 末永裕之, 大島伸一：Laparoscopic nephrectomy $の$ 試み. 日泌会誌, 83, 390-394, 1992.

2) Ono, Y., Kinukawa, T., Sahashi, M., Katoh, N., Matsuura, O., Hirabayashi, S., Yamada, S., Suenaga, H. and Ohshima, S. : Laparoscopic nephrectomy in 10 patients with renal disease Jpn. J. Endourol. E.S.W.L., 5, 146-149, 1992.

3) Clayman, R.V., Kavoussi, L.R., Soper, N.J., Dierks, S.M., Merteyk, S., Darcy, M.D., Roomer, F.D., Pingleton, E.D., Thomas, P.G. and Long, S. R. : Laparoscopic nephrectomy: Initial case report. J. Urol., 146, 278-282, 1991.

4) Coptcoat, M., Joyce, A., Rassweiler, J. and Popert, R. : Laparoscopic Nephrectomy: The Kings' Clinical Experience. AUA 87th Anual Meeting at Washington D.C., May, p. 13, 1992.
5）東原英二, 亀山周二, 田中良典, 堀江重郎, 佐山 孝, 狩野宗英, 朝蔭裕之, 㝨和田滋, 奴田原紀久雄, 阿曽佳郎：腹腔鏡下腎摘出術. 動物実験及びその 臨床的応用. 日泌会誌, 83，395-400，1992.

6）鈴木和雄，他：Personal communication

7）松田公志, 内田潤二, 川村 博, 小松洋輔, 藤瀬久 美子, 寺地敏郎, 堀井泰樹, 吉田 修: 腹腔鏡下腎 摘除術の経験。泌尿紀要, 38, 759-965, 1992.

8) Clayman, R.V., Kavoussi, L.R., Albara, D., Chandhoke, P., Soper, N.J. and Figenshau, R.S. : Laparoscopic Nephrectomy; Initial Clinical Series. AUA 87th Annual Meeting at Washington D.C., May, p. 13, 1992.

9) Robson, C.J.: Radical nephrectomy for renal cell carcinoma. J. Urol., 89, 37-42, 1963.

10) Wood, D.P. Jr.: Role of lymphadenectomy in renal cell carcinoma. Urol. Clin. North Am., 18, 421-426, 1991.

（1993年 2 月 5 日受付， 4 月 17 日受理） 